\title{
Socioeconomic Rights, Extraterritorially
}

\section{Ralph Wilde*}

To be published as Chapter 9 in Community Obligations in Contemporary International Law (Eyal Benvenisiti and Georg Nolte (eds.), OUP, forthcoming, 2018) 381-395

PRE-EDITED, PRE-PUBLICATION DRAFT, PLEASE CHECK AGAINST PUBLISHED VERSION. RALPH WILDE 2018

ETOs [extraterritorial human rights obligations in the field of socio-economic rights] are a missing link: Without ETOs, human rights could not assume their proper role as the legal bases for regulating globalization. With ETOs, an enabling environment for ESCRs can be generated, the primacy of human rights can be implemented, climate change and eco-destruction can be stopped, the dominance of big money broken, TNCs regulated, and IGOs made accountable. ${ }^{1}$

\section{Introduction}

What is the value of ideas of international human rights in the struggle against global poverty and economic inequality? This question is not new, but recently a new aspect to it has emerged: what

* University College London, University of London. The work on this chapter was funded by the European Research Council. My warm thanks to Dr. Karen da Costa for excellent research assistance. This contribution contains ideas first set out in Ralph Wilde, Dilemmas in Promoting Global Economic Justice Through Human Rights Law, in THE FRONTIERS OF HUMAN RIGHTS: EXTRATERRITORIALITY AND ITS CHALLENGES 127 (Nehal Bhuta ed., 2016).

1 Our Work, Extraterritorial Obligations (ETOs), ETOs: THE ETO CONSORTIUM, http://www.etoconsortium.org/en/main-navigation/our-work/ (last visited June 7, 2017). 
contribution might international human rights law make, on the basis of an "extraterritorial" orientation, as far as state obligations are concerned? Such an enquiry has been foregrounded by a major international initiative by experts and activists: the 2011 Maastricht Principles on the Extraterritorial Obligations of States in the Area of Economic, Social and Cultural Rights (hereinafter the 'Principles').2 The present chapter offers a critical evaluation of this enquiry, using the Principles

${ }^{2}$ MAAstricht Principles on EXTRATERritorial Obligations of StATES IN THE AREA OF ECONOMIC, SOCIAL AND CUltural RighTs (adopted Sept. 28, 2011), https://www.fidh.org/IMG/pdf/maastricht-eto-principles-uk_web.pdf [hereinafter Principles]. The official commentary to the Principles is Olivier De Schutter et al., Commentary to the Maastricht Principles on Extraterritorial Obligations of States in the Area of Economic, Social and Cultural Rights, 34 Hum. RTS. Q. 1084 (2012). For other academic writing on the Principles, see CASES AND CONCEPTS ON EXTRATERritorial Obligations IN THE AREA OF ECONOMIC, SOCIAL AND CUltural Rights (Fons Coomans \& Rolf Künnemann eds., 2012); Global Justice, State DutiES (Malcolm Langford et al. eds., 2013); Olivier De Schutter, Foreword, in CASES AND CONCEPTS On EXTRATERritorial ObligATIONS IN THE AREA OF ECONOMIC, SOCIAL AND CUltural Rights, supra, at v; Fons Coomans \& Rolf Künnemann, General Introduction, in CASES AND CONCEPTS ON EXTRATERritorial Obligations In THE AREA OF ECONOMic, SOCIAL AND CUltural Rights, supra, at 1; Malcolm Langford et al., Introduction: An Emerging Field, in Global Justice, StATE DutiEs, supra, at 3; Mark Gibney, On Terminology: Extraterritorial Obligations, in Global Justice, StATE Duties, supra, at 32; Malcolm Langford \& Mac Darrow, Moral Theory, International Law and Global Justice, in GLOBAL JuSTICE, STATE DuTIES, supra, at 419; Wouter Vandenhole, Beyond Territoriality: The Maastricht Principles on Extra-Territorial Obligations in the Area of Economic, Social and Cultural Rights, 29 NeTH. Q. HuM. RTS. 429 (2011); Margot E. Salomon \& Ian Seiderman, Human Rights Norms for a Globalized World: The Maastricht Principles on the Extraterritorial Obligations of States in the Area of Economic, Social and Cultural Rights, 3 GloBAL PoL'Y 458 (2012) ; Wouter Vandenhole, Emerging Normative Frameworks on Transnational Obligations, (European Univ. Inst. Robert Schuman Ctr. for Advanced Studies, Working Paper no. 2012/17, 2012), http://cadmus.eui.eu/handle/1814/21874; Margot E. Salomon, The Maastricht Principles on Extraterritorial Obligations in the Area of Economic, Social and Cultural Rights: An Overview of Positive "Obligations to Fulfil", EJIL:TALK! (Nov. 16, 2012), https://www.ejiltalk.org/the-maastricht-principles-on-extraterritorial-obligationsof-states-in-the-area-of-economic-social-and-cultural-rights-and-its-commentary-an-overview-of-positive-obligationsto-fulfil/; Fons Coomans, Situating the Maastricht Principles on Extraterritorial Obligations of States in the Area of Economic, Social and Cultural Rights (Apr. 26, 2013) (unpublished manuscript), http://ssrn.com/abstract=2256836. 
and its associated Commentary as a case study. This case study is used because on the fundamental bases for obligation — conceptions of 'power' and 'cooperation' that will be reviewed herein — the Principles and the Commentary reflect how many international legal experts, not only those associated with the Principles, view the general contours of the law in this area. The documents thus offer a certain way to make the case for invoking international human rights law as a means of combating global poverty and economic inequality. In engaging this critical appraisal, I adopt the method of 'immanent critique,' assessing the merits of the substance of the legal requirements according to the claims made about the law by the proponents of it, such as the claim made by the ETO Consortium in the extract above. I do this because such claims reflect how many in the field of international public policy view the value of the legal framework, and also the messages about this, like the above claim, which are being impressed upon those NGOs working in the field of international economic justice.

\section{Extraterritoriality of Socioeconomic Rights: Meaning and Historical Context}

The 'extraterritorial' dimension of state obligations in international human rights law concerns the question of norms addressing the relationship between people located in one part of the world and people located in other parts of the world, when these differences are conceived in terms of territorial title in international law. The 'extraterritorial' approach classifies people and their rights, and states and their obligations, according to the legal status of the territory within which the people reside and the nature of the connection between that status and the legal identity of the state concerned. Human rights are 'territorial' when opposable to the state in whose territory the individuals reside. They are 'extraterritorial' when opposable to a foreign state lacking sovereignty-as-title over the territory where the individuals reside.

Seeking to address global poverty and economic inequality through this approach involves challenging an exclusively 'territorial' conception of state obligations in human rights law, to include also 'extraterritorial' obligations, especially where the territorial and the extraterritorial distinction maps on to, respectively, places in the world where people are relatively economically advantaged, 
and places in the world where people are relatively economically disadvantaged. In other words, put more crudely, to make economically advantaged states obliged to address the economic position not only of people within their territory, but also of poor people extraterritorially.

International law has for some time been a site of efforts to challenge global poverty and economic inequality, notably in the period during the main wave of post-World War II decolonization, when newly independent, former colonial and relatively economically disadvantaged states sought to promote a 'New International Economic Order' (NIEO). This period saw the promotion of a 'right to development' which would oblige economically advantaged states to enable, including through resource and technology transfer, economic development in economically disadvantaged states. Such efforts were hampered by general resistance by wealthier states, with articulation and codification efforts residing largely in General Assembly resolutions at the UN, vulnerable to the challenge that such 'soft law' is insufficient by itself, absent the necessary developments in treaty and/or customary law, to be normative.

By contrast, international human rights law, which was also being established at this time, met the standard test for normativity, being articulated not only in the UN General Assembly's Universal Declaration of Human Rights (UDHR), but also in a range of treaties and other instruments. Although many of these instruments address economic rights and contain provisions that speak to issues of international economic justice, the main focus of attention with respect to understandings and interpretations of all human rights instruments began as territorial, being concerned predominantly with the relationship between individuals and the state within which they are located. ${ }^{3}$

Internationally, efforts to promote international economic justice were dominated by initiatives outside international human rights treaty-based mechanisms, building on the earlier NIEO-focus in the UN political organs. The Bretton Woods institutions (BWIs), the World Bank and the International Monetary Fund (IMF), became the leading multilateral bodies concerned with 'development,' cohabiting with sui generis political initiatives such as the $0.7 \%$ of GDP target for the

\footnotetext{
${ }^{3}$ See, e.g., Coomans \& Künnemann, supra note 2, at 1.
} 
provision of development assistance (which came out of the 'right to development' initiatives), campaigns for debt relief and the elimination of tariffs and subsidies, and the 'Millennium Development Goals' (MDGs) and successor ‘Sustainable Development Goals' (SDGs). The World Bank, the IMF and later the World Trade Organization (WTO) became sites of resistance for social movements seeking different, more radical and transformatory approaches to global poverty and economic inequality.

Later in the lifespan of post-World War II international human rights law, however, it is possible to identify greater receptiveness to addressing extraterritorial situations when human rights treaties are discussed, interpreted and applied by expert bodies, courts and tribunals, states, NGOs and independent experts. The earliest and most prominent trend in this regard is contained in the jurisprudence relating to the European Convention on Human Rights (ECHR) (notably in decisions about the Turkish presence in Northern Cyprus), and in subsequent decisions relating to the International Covenant on Civil and Political Rights (ICCPR) and other regional and global human rights instruments. This development was heightened by a greater critical focus in the international public consciousness with respect to the impact on human rights of U.S.-led extraterritorial activities associated with/occurring during and continuing after the 'War on Terror.' Courts and expert bodies being called upon by petitioners to bring these activities within the regulation of human rights treaties have considered this through the aforementioned device of 'extraterritoriality': conceiving the spatial reach of human rights obligations as being either 'territorial' or 'extraterritorial,' and setting out tests for when the latter form of obligations would be triggered. ${ }^{4}$

The push towards the affirmation and delineation of extraterritorial human rights treaty obligations can be seen perhaps to have been most prominent and developed in the field of civil and

\footnotetext{
${ }^{4}$ On the case law relating to civil and political rights, see, for example, the discussion and sources cited in Ralph Wilde, The Extraterritorial Application of International Human Rights Law on Civil and Political Rights, in ROUTLEDGE HANDBOOK ON INTERNATIONAL HUMAN RightS LAW 635 (Scott Sheeran \& Nigel Rodley eds., 2013).
} 
political rights when this set of rights is compared with economic, social and cultural rights. The relative difference can be explained in part due to the aforementioned prominence given to certain concerns relating to rights in the former category in the period after the attacks on the U.S. on 9/11, both territorial and extraterritorial. Equally, it is partly explicable because of the greater opportunity for and significance of international expert review regarding civil and political rights resulting from the more long-standing existence and state acceptance of jurisdiction of bodies engaged in such review exclusively, notably the European Commission and Court of Human Rights and the UN Human Rights Committee. Also, of the only three bodies that operate as courts and issue binding judgments with respect to complaints, the two applying instruments that cover economic, social and cultural rights - the Inter-American Court of Human Rights and the African Court of Human and People's Rights - have had less opportunity to contribute to case law compared to the European Court of Human Rights; and although the International Court of Justice, as part of its general move into human rights law, has made important pronouncements on the extraterritorial application of human rights law, including certain instruments covering economic, social and cultural rights, this has happened only recently, and in only a few instances, with significance more in the arena of normclarification than norm-enforcement. ${ }^{5}$

Whatever the cause, it is clear that when the extraterritorial application of human rights law has been addressed, whether before international interpretation bodies as in the jurisprudence mentioned above, or in popular discourse, or in academic literature, there had been until relatively recently a tendency for civil and political rights to be given greater and sometimes even exclusive focus when compared with economic, social and cultural rights. Writing in 2007, Alan Boyle and Christine Chinkin observed that "despite human rights reports setting out the adverse impact of neo-liberal economic ideology and globalization on the human rights of the poor, of women and of other

\footnotetext{
${ }^{5}$ See, e.g., the discussion and sources cited in Ralph Wilde, Human Rights Beyond Borders at the World Court: The Significance of the International Court of Justice's Jurisprudence on the Extraterritorial Application of International Human Rights Law Treaties, 12 CHINESE J. INT'L L. 639 (2013).
} 
vulnerable peoples, there has been little real attempt to address these issues within the framework of international law." 6

\section{The ETO Project - An Introduction}

There is now an effort to alter the balance of the agenda of extraterritoriality within international human rights law in favor of economic, social and cultural rights, building on important but sparse developments in this field, from certain statements made by international expert bodies and important early academic interventions. This is being spearheaded by a group of experts and activists, including members of international human rights expert bodies, NGO staffers and university professors. They are backed up by a broader expert/activist network including many NGOs working in the field of human rights generally and rights in the area of international economic justice and equality in particular, called the Extraterritorial Obligations Consortium, or ETO Consortium for short, the source of the quotation at the beginning of this chapter. ${ }^{7}$

In 2011, forty members of this movement adopted the Maastricht Principles on the Extraterritorial Obligations of States in the Area of Economic, Social and Cultural Rights, hereinafter referred to as the 'Principles. ${ }^{8}$ This was followed a year later by a detailed and lengthy legal Commentary by the six members of the drafting committee of the Principles, issued as an authoritative explanation for

${ }^{6}$ AlAn Boyle \& Christine CHINKIn, THE MAKING OF INTERNATIONAL LAW 18 (2007).

7 Information available at ETOs: THE EXTRATERRITORIAL OBLIGATIONS (ETO) CONSORTIUM, http://www.etoconsortium.org (last accessed Nov. 29, 2016). I am an academic member of the Consortium, which I joined after the Maastricht Principles had been adopted (an overview of the academic members is available at About Us, Academic Members, ETOs: THE EXTRATERritorial Obligations (ETO) CONSORTIUM, http://www.etoconsortium.org/en/main-navigation/about-us/academic-members (last accessed Dec. 29, 2016). I played no role, formal or informal, in the process that led to their adoption.

${ }^{8}$ Principles, supra note 2. 
what was meant in each of the Principles. ${ }^{9}$ Backed up by this Commentary, the Principles attempt to codify comprehensively in a series of treaty-like provisions the main contours of an international human rights law regime with respect to the actors and subject-matter in its title.

The present chapter draws selectively from these documents and the legal norms they set out, focusing on the fundamental bases for extraterritorial obligations relating to economic rights in international human rights law: what will be described below as conceptions of 'power' and 'cooperation.' These fundamental bases for obligation are the key features of the legal regime as far as the potential it has to promote international economic inequality and combat global poverty. The following analysis sets out what the Principles and the Commentary say about these bases for obligation, because, as mentioned earlier, in this respect the documents reflect a widely shared approach to invoking international human rights to address global poverty, and so can form the basis for a critical appraisal of the substantive merits of these areas of obligation.

There is now a global campaign, spearheaded by the ETO Consortium, to have the Maastricht Principles and more broadly international human rights law placed at the center of global activism on ending global poverty and economic inequality. This campaign is based on the proposition, as reflected in the quotation at the start of this chapter by the ETO Consortium, that international human rights law has a primary, perhaps even preeminent, positive role in combating global poverty and economic inequality and regulating economic globalization. Thus the law is invoked to intervene in a highly contested area of public policy, where a broad range of very different preferences could be adopted and promoted, and/or avoided and ignored, and/or undermined, through and by it. It is important, then, to ask: which polices are given preference over the alternatives by international human rights law as it is understood by the leading experts? What is possible, what is prevented, what is included, what is excluded, in the wide range of ways that might exist to order the world so as to better combat global poverty and economic inequality? What follows addresses this question by

\footnotetext{
${ }^{9}$ De Schutter et al., supra note 2. On the connection between the members of the drafting committee and the authors of the Commentary, see id., at 1084 n.f.
} 
considering some of the main features of the substantive policy framework enshrined in the fundamental areas of legal obligation, using the Principles and the Commentary as a resource on how these areas of legal obligation are understood by the leading experts.

Before engaging in a detailed appraisal of the substantive merits of the policy preferences embedded in the main contours of the legal regime, it is necessary, in the present section, to set out, by way of shorthand description, the general conceptions of areas of obligation in the legal regime, and to introduce the key questions of policy that need to be asked when appraising the substantive value of this legal framework.

International human rights law obligations in the field of socioeconomic rights are triggered in two main circumstances. These two triggers are summarized in Principle 8 of the Maastricht Principles thus:

a) obligations relating to the acts and omissions of a State, within or beyond its territory, that have effects on the enjoyment of human rights outside of that State's territory; and b) obligations of a global character that are set out in the Charter of the United Nations and human rights instruments to take action, separately, and jointly through international cooperation, to realize human rights universally. ${ }^{10}$

The obligations described in paragraph (a) conceptualize a trigger for the operation of legal regulation if and when a particular type of power relationship operates between a state and people outside its territory. Only if this power relationship is present are the obligations triggered. According to this approach, the very existence of obligations operates on the basis of a default position of exclusively territorial significance (in terms of the location of the rights-holders) which is departed from if a particular power relationship is considered to exist extraterritorially. In what follows the

\footnotetext{
${ }^{10}$ Principles, supra note 2, princ. 8.
} 
notion of a 'power' conception of extraterritorial obligations will be used as shorthand for this feature of the normative framework.

The obligations described in paragraph (b) arise not only as a consequence of the existence of a power relationship extraterritorially but, rather, in any event. They are concerned not with regulating exceptional power relationships if and when they arise, but, rather, with addressing the 'normal' situation of economic interdependence between states understood as a permanent state of affairs, seeking to graft onto this certain requirements on the part of states in a position to do so to improve economic rights outside their territories, described as being about 'cooperation.' Thus there is no trigger that needs to be present in order for the obligations to be in operation; they operate all the time. In what follows, the notion of obligations concerned with 'cooperation' will be used as shorthand for this feature of the normative framework.

\section{What Is at Stake?}

Clearly there are many and varied ways in which the structures of the global economy and international economic relations could be changed in order to combat poverty and economic inequality, and a range of different rationales for these changes. The choice between these options is contested, implicating different conceptions of economic and political theory, and historical record, involving varying degrees of difference, from modest reform to radical transformation of the status $q u o$, and a matter on which a wide range of stakeholders, from grassroots civil society activists to the elites of the international economic system, are and will be engaged. Bearing all of this in mind, how might what international human rights law is said to offer implicate these broader debates? Whose agenda does it further, and whose does it undermine?

The point of this enquiry is not to adopt a particular substantive approach to, and/or the interests of a particular stakeholder about, how the global economy might be ordered better. Rather, it is to ask how the law might mediate the choices made about, and the fortunes of particular stakeholders in relation to, these contests, bearing in mind the particular policy preferences embedded in legal norms. Whereas it is for broader debates and processes to contest and determine the merit of these 
preferences, it is important to know what they are, so as to know what particular agenda is being furthered by advocacy of the law in this field.

In the ensuing analysis, the following considerations will be borne in mind. In the first place, in a situation of complex economic independence, a multitude of different causal and power relationships and linkages operate in all sorts of ways and at all sorts of levels to determine the economic position of most people in the world. Economies are intertwined, and operate on the basis of many varied and dynamic power and control hierarchies. How does international human rights law understand and seek to mediate these relationships? In the second place, how does the way the law is conceived relate to rationales that underpin options for realizing international economic equality and the range of possible options themselves? The following two sections analyze the potential and the limitations of the two key features of the substantive legal regime.

\section{Ground One: Power - Description and Critique}

It will be recalled that the 'power' basis for extraterritorial human rights obligations is concerned with defining a set of circumstances extraterritorially (sometimes with a territorial origin) that have to be met before, obligations are triggered. These circumstances are conceived in Maastricht Principle 8 thus: "the acts and omissions of a State, within or beyond its territory, that have effects on the enjoyment of human rights outside of that State's territory."11

A plain reading of this provision suggests an idea that is potentially very broad in what it takes in by way of economic interdependence, because of the inclusion of omissions as well as acts: the idea of all "effects," defined simply as such, as a basis for obligation, and how it covers acts and omissions existing not only extraterritorially but also territorially. However, this expansive potential is lessened considerably by Maastricht Principle 9, which states that

\footnotetext{
${ }^{11} I d$. princ. 8.
} 
A State has obligations to respect, protect and fulfil economic, social and cultural rights in any of the following:

a) situations over which it exercises authority or effective control...;

b) situations over which State acts or omissions bring about foreseeable effects on the enjoyment of economic, social and cultural rights, whether within or outside its territory; c) situations in which the State...is in a position to exercise decisive influence ... to realize economic, social and cultural rights extraterritorially. ${ }^{12}$

Also relevant is Maastricht Principle 13, which states that

States must desist from acts and omissions that create a real risk of nullifying or impairing the enjoyment of economic, social and cultural rights extraterritorially. The responsibility of States is engaged where such nullification or impairment is a foreseeable result of their conduct. $^{13}$

The import of these provisions is to set up a more qualified and varied approach to conceiving power so as to trigger obligations relating to the enjoyment of human rights extraterritorially.

On the one hand, if the state is present on the ground extraterritorially, exercising "authority or effective control," then it has a broad obligation to "respect, protect and fulfil" economic, social and cultural rights there (Maastricht Principle 9a). This retains the breadth of the original articulation in Maastricht Principle 8, but is limited to unusual situations where states are present in this kind of direct way outside their territories. It reflects how the ICCPR and the ECHR have been understood to apply extraterritorially, via a definition of the term "jurisdiction" in these treaties to include the exercise of effective control extraterritorially. ${ }^{14}$ Similarly, the term "jurisdiction" (which is used in the heading for Maastricht Principle 9) was invoked by the International Court of Justice, without

\footnotetext{
${ }^{12} I d$. princ. 9.

${ }^{13}$ Id. princ. 11 .

${ }^{14}$ On this, see, for example, Wilde, supra note 4, at 641-44.
} 
supporting authority, as an extraterritorial trigger based on the exercise of effective territorial control for the obligations in the International Covenant on Economic, Social and Cultural Rights (ICESCR), even though the term is not used in that treaty. ${ }^{15}$

On the other hand, the more commonplace projection of power extraterritorially that falls short of direct extraterritorial presence is covered only if, on the one hand, states are in a position to exercise "decisive influence" to "realize" economic, social and cultural rights (Maastricht Principle 9c), or, on the other hand, in the context of "acts and omissions" that have "foreseeable effects on the enjoyment of economic, social and cultural rights" (Maastricht Principle 9b), or if it is "foreseeable" that they create a "real risk of nullifying or impairing" such enjoyment (Maastricht Principle 13).

We see, then, that the human rights law regulation of all forms of economic interaction other than the narrow circumstances of direct extraterritorial presence on the ground is conventionally understood to be either limited to a high threshold of "direct influence," or, otherwise, is concerned with power relationships that are in some way deemed to be harmful (cf. "nullifying or impairing"). The suggestion that this is about harm is supported in the Commentary to the Maastricht Principles, which explains the general distinction between the 'power' and 'cooperation' bases for obligations in Maastricht Principle 8 paragraphs a) and b), the former being the present focus of attention, thus:

... the obligation to provide assistance to other states in order to strengthen respect for human rights in those states, in the absence of any particular link between a state and the denial of human rights in those states, arises only by virtue of the obligation of a global character as described in Principle 8 (b). ${ }^{16}$

Here, then, is the idea that the 'power' conception for obligations can be understood holistically as being about a "particular link between a state and the denial of human rights." Furthermore, the

\footnotetext{
${ }^{15}$ Legal Consequences of the Construction of a Wall in the Occupied Palestinian Territories, Advisory Opinion, 2004 I.C.J. Rep. 136, II 112 (July 9).

${ }^{16}$ De Schutter et al., supra note 2, at 1101-02.
} 
language suggests that of the two types of extraterritorial obligations, only 'power' is concerned with responsibility arising out of harm; 'cooperation' (in Maastricht Principle 8(b)) is described in language suggesting a different rationale and objective (the word 'cooperation' itself, and the way the substantive action required of a state here is to "provide assistance" - is hardly the language of reparation for harm).

The language used also suggests that the nature of harm is to be limited from the full extent of possible options available - only a "particular link" which has to be foreseeable and involving a "real risk." The relatively limited definition of causation is underscored by the Commentary, which states that

Principle 9 (b) acknowledges that the obligations of a state under international human rights law may effectively be triggered when its responsible authorities know or should have known the conduct of the state will bring about substantial human rights effects in another territory. Because this element of foreseeability must be present, a state will not necessarily be held liable for all the consequences that result from its conduct where the proximity between that conduct and the consequences is remote. ${ }^{17}$

In the same way, the Commentary to Maastricht Principle 13 states that "[f]oreseeability serves an important limiting function by ensuring that a state shall not be surprised with claims of responsibility for unforeseeable risks that are only remotely connected to its conduct."18

Clearly discussion and disagreement can be had about, and work in related areas of law such as the law of state responsibility drawn upon in considering, how these key terms can and should be defined legally, from the notion of 'particular' types of harm that are 'proximate' and 'foreseeable' and not 'remote' to the idea of a 'real risk' with effects that are 'substantial.' But whichever approach is taken in the range of options for the scope of liability here, from narrow to broad, more

\footnotetext{
${ }^{17}$ Id. at 1109.

${ }^{18} I d$. at 1113.
} 
fundamentally the range itself only covers a subset of the wide linkages that exist globally between national economies, given how they are intertwined in an acute, complex and constant fashion. This is a limited notion of international economic relations in not taking in the full potential for causal relationships that can mediate the state of economic rights.

\section{Ground Two: Cooperation and Assistance- Description and Critique}

[G]overnments may feel bound to act, but that feeling of obligation may simply come from their own sense of altruism rather than a belief that human rights bind all governments to help if the government most directly responsible fails to fulfil its duties. ${ }^{19}$

The second area of obligations, those relating to 'cooperation' in the realization of economic, social and cultural rights extraterritorially, would suggest that the idea of "help" is, indeed, derived not simply from altruism but also legal obligation. But what is the scope of this help and, indeed, what does conceiving it as help and associating it with the idea of "altruism" indicate about its nature and potential?

As previously indicated, the 'cooperation' obligations are not conceived to be triggered by the existence of a particular power relationship between a state and an extraterritorial human rights situation. Rather, they operate generally. As such, they have the potential to be of much wider relevance to international economic relations, and so to be much more important to efforts to combat global poverty and economic inequality, than the first set of obligations.

It will be recalled that Maastricht Principle 8 defines the 'cooperation' category of extraterritorial obligations as being "of a global character... to take action, separately, and jointly through

19 Andrew Heard, Human Rights: Chimeras in Sheep's Clothing? (unpublished manuscript) (1997), http://www.sfu.ca/ aheard/intro.html, cited in Langford et al., supra note 2, at 8. 
international cooperation, to realize human rights universally." ${ }^{20}$ The main human rights instrument enshrining the obligation to cooperate in this way is the ICESCR, in Article $2 .{ }^{21}$ Drawing on this, Maastricht Principle 9 states that

A State has obligations to respect, protect and fulfil economic, social and cultural rights in ... c) situations in which the State, acting separately or jointly, whether through its executive, legislative or judicial branches, is in a position ... to take measures to realize economic, social and cultural rights extraterritorially. ${ }^{22}$

This law on 'cooperation' includes, arguably as its most important norm, and falling within the particular obligation to "fulfil" in this area, an obligation "to provide assistance," as reflected in Maastricht Principle 33. ${ }^{23}$ The obligation to provide assistance to enable the realization of socioeconomic rights extraterritorially is the only area of this legal regime that speaks to the fundamental issue of financial, technological and resource transfer across borders from the economically privileged to the economically disadvantaged in order to combat poverty and reduce economic inequality, not simply, as in the 'power' area of law, to make amends for certain forms of foreseeable and non-historical harm. It is the area within which the 'right to development,' economic redistribution, and development assistance and aid, including the setting of targets for such aid, must fit, if they fit at all, as far as the contours of international human rights law are concerned.

The Maastricht Principles Commentary also invokes the duty to provide assistance. It asserts that "[d]espite its provision in binding international instruments, disagreement persists as to the legally binding nature of the obligation of international cooperation as expressed in" the ICESCR. ${ }^{24}$ This is

\footnotetext{
${ }^{20}$ Principles, supra note 2, princ. 8.

${ }^{21}$ International Covenant on Economic, Social and Cultural Rights, Dec. 16, 1966, 993 U.N.T.S. 3 [hereinafter ICESCR].

${ }^{22}$ Principles, supra note 2, princ. 9.

${ }^{23}$ Id. princ. 33 .

${ }^{24}$ De Schutter et al., supra note 2, at 1094.
} 
a significant observation when situated within the law of human rights extraterritorially, and, more broadly, within international human rights law in particular and international law as a whole. Actually, disagreement exists across the board in many areas of international law, and, notably, in relation to many aspects of the law of the extraterritorial application of human rights. However, this is the only rule on extraterritoriality where the 86-page Commentary invokes the existence of "disagreement." ${ }^{25}$ Given the wider context of disagreement in international law, one has to ask why a particular rule is singled out as the only one in relation to which disagreement exists, especially when, as the statement acknowledges, the rule is expressly articulated in a treaty. Moreover, this approach is in marked contrast to the way, as mentioned above, the Principles seem to adopt the "jurisdiction" basis for triggering obligations in this sphere, and the effective control basis on which that term has been defined in case law, as operative in relation to economic, social and cultural rights, even though the term is not contained in the ICESCR and the case law defining it in this way is derived, as mentioned above (the dictum from the ICJ), from the other human rights treaties that do use it and are limited to civil and political rights.

The transposition of the standard from the law on civil and political rights is also significant in two further respects. In the first place, actually, even in that area of law extraterritorial applicability is disputed; there is "disagreement." ${ }^{26}$ In the second place, the area of applicability that the standard is being transposed to - economic rights in situations where control and authority is exercised 'on the ground' extraterritorially - addresses activities by states which are, as mentioned, although significant when they happen, unusual when situated within the broader projection of power by states extraterritorially and the effects of this on the economic position of people worldwide. Given the limited conception of the 'power' test for applicability, as reviewed above, much of the broader picture is only going to be addressed by the law through the alternative 'cooperation' conception of responsibilities. Yet here, it seems, the very existence of a binding obligation is in question. The

\footnotetext{
${ }^{25}$ In a footnote it is also acknowledged that there are disagreements about the "Lotus presumption." Id. at 1138 n.136.

${ }^{26}$ See, e.g., the discussion and sources cited in Wilde, supra note 4.
} 
consequence of all this is that there is a bold affirmation of normativity, where such normativity is actually disputed, in relation to unusual situations, and a questioning of normativity, despite the existence of binding treaty provisions on the issue, in relation to a much broader area of international economic relations.

In this context, is hard not to view the questioning of the binding nature of the obligation to cooperate internationally as overcompensation. It seems that in this area it is deemed prudent to play it safe in terms of the extent to which economically privileged states will have to act and international economic relations will have to be altered - so safe, actually, that objections to the binding nature of express provisions of a treaty will be deferred to.

It can hardly be a surprise, then, that what follows from this is very limited. The Commentary concludes that on the question of the provision of assistance, it is probably only possible to say that states should coordinate with each other, including on the allocation of responsibilities, and have foreign assistance programs. ${ }^{27}$ Within this, on the crucial question of how much resources are to be allocated to such programs, the Commentary adopts the standard 'progressive' approach adopted in relation to positive obligations to fulfil economic, social and cultural rights generally, that states have to assist to the maximum of their available resources. ${ }^{28}$

The progressive test requiring best efforts ("in a position to do so") to be made in the area of fulfilling economic, social and cultural rights is, of course, a challenging idea even if just applied to the domestic context (given that, for example, the level of available resources is not fixed, being determined, rather, by prior matters involving contested choices between fundamentally different economic and political systems). But when it is applied to extraterritorial assistance, it has to reckon

\footnotetext{
${ }^{27}$ Principles, supra note 2, princs. 30, 33. See also id. princs. 28-29, 31-32, 34-35, and the relevant sections of De Schutter et al., supra note 2.

${ }^{28}$ Principles, supra note 2, princ. 33. See also, on coordination, id. princ. 30 , and on capacity and resources, princ. 32 , and the relevant sections of De Schutter et al., supra note 2. On the 'progressive' standard, see ICESCR, supra note 21, art. 2 .
} 
with a new complicating factor: how are resources to be divided up between welfare 'at home' and welfare 'abroad,' assuming a zero sum equation? This is, of course, a crucial matter that goes to the heart of a regime that purports to conceive extraterritorial norms in the area of economic rights.

There is, actually, an international standard of some pedigree that speaks to the crucial quantum question. As the Commentary acknowledges, the aforementioned target of $0.7 \%$ of GNP to be allocated to overseas development assistance by wealthier countries has been affirmed in a range of instruments. ${ }^{29}$ This is the closest that international law has come to a benchmark for economic redistribution through aid, thereby speaking to the crucial issue of where the balance is to be struck between welfare at home and welfare extraterritorially.

However, the Commentary does not address the fundamental matter of whether or not this target is, or might become, legally obligatory. ${ }^{30}$ In their separate writings on the Principles, some of those involved in the initiative reference the resistance of wealthier states to the notion that there is a legal obligation to cooperate in general, and an obligation to provide particular levels of assistance in particular. ${ }^{31}$ This may be, then, a pragmatic decision made to accept, not challenge, the resistance of such states to obligation in this area, in order, presumably, to ensure that they come on board on the regime more generally, which, in order for this logic to work, has to be worth the price paid in jettisoning some of the core aspects of the obligation to cooperate. But the merits of this position are not self-evident, requiring a considered cost-benefit analysis that is reasoned and persuasive. No such analysis is being conducted. The fact that this compromise has been made is not even acknowledged, let alone justified. Bearing in mind the foregoing analysis, what can be said about the substantive

${ }^{29}$ G.A. Res. 2626 (XXV), International Development Strategy for the Second United Nations Development Decade, $\mathbb{I} 43$ (Oct. 24, 1970); Preparatory Committee for the International Conference on Financing for Development Fourth Session, Revised draft outcome prepared by the Facilitator, II 42, U.N. Doc. A/AC.257/32 (Dec. 7, 2001); G.A. Res. 63/239, Doha Declaration on Financing for Development: Outcome Document of the Follow-up International Conference on Financing for Development to Review the Implementation of the Monterrey Consensus, II 43 (Mar. 19, 2009).

${ }^{30}$ De Schutter et al., supra note 2, at 1152 .

${ }^{31}$ See Salomon, supra note 2; Coomans, supra note 2, at 6; Langford et al., supra note 2, at 26. 
nature of the legal regime on 'cooperation' as set out by the Maastricht experts? The very existence of an obligation to assist is called into question, and no proper consideration is given to the crucial question of how resources are to be allocated by more economically advantaged states as between welfare at home and welfare internationally, let alone the matter of whether the $0.7 \%$ target of GNP, which would in any event be remarkably modest, is or might be binding. More fundamentally, the language of 'assistance' and 'cooperation' indicates very limited notions of action. It suggests a preexisting reality taken as a given and, moreover, in relation to which it locates responsibility for realizing socioeconomic rights exclusively in the territorial state, as in the quotation from Andrew Heard at the start of this section, cited by Langford, Vandenhole, Scheinin and van Genugten, ${ }^{32}$ with its reference to the provision of "help if the government most directly responsible fails to fulfil its duties." Other states then 'assist' that government in this, although not by any clear level in terms of resources. Broader, more fundamental approaches, including of redistribution, that would involve a more radical transformation of the world economy, are not considered.

This is a model that takes the existing structures of the global economy as a given, grafting onto them relatively minor modifications which do not in any significant way challenge things to bring about a significant change in levels of poverty and economic inequality across borders. There is no place here for the kind of radical restructuring of the world economy that would be of much more significance to the global poor, the call for which, of course, is associated with social movements in the global South and with certain ideas from postcolonial and Third World approaches to international law (TWAIL).

\section{Conclusion: The Appropriateness of the ETO Framework}

What is the merit of an approach that is grounded in human rights law when it comes to the quest to combat global poverty and economic inequality? Will the law make a big difference? If not, and its

\footnotetext{
${ }^{32}$ Langford et al., supra note 2.
} 
potential is more limited, should the current legal settlement serve as the departure point, from which to go further, making refinements? Is it the right place to start?

The foregoing analysis suggests, as mentioned, that as far as the view taken on it by the ETO initiative is concerned, the current legal regime takes the fundamental structures of global economic relations largely as is, grafting onto this relatively discrete areas of liability, concerned either with certain forms of power relations and harm understood in terms of direct or foreseeable causation, or vague notions of 'cooperation' that do not extend to particular levels of financial and resource transfer.

It would seem, then, that if this view of the law were doctrinally correct, some of the grand claims made for the potential of international human rights law in the context of global poverty and economic inequality, as indicated in the quotation at the start of this chapter, would not stand up to scrutiny. It has to be asked, then, whether a campaign to put human rights obligations at the center of activism in this field is a valuable use of the limited time and resources of those involved. And, in consequence, the concern must also be that the modest nature of the substantive law creates a danger that it will merely serve to bolster the continuation of the status quo, which can now be further legitimated by states through claims to being 'human rights compliant.'

But could not a more modest position be adopted, that certain limited improvements might be effected at the margins, and that more radical efforts seeking transformatory changes can be, and indeed perhaps should be, left to broader struggles taking place outside the structures of international human rights law? Such broader struggles could, as human rights by definition cannot, involve ideas that offer more fundamental challenges to the structural aspects of global economic life, from the division of the world into sovereign states itself to the substantive models of economics that form the basis for the world economy. Modesty in the expectations made of the law can also be used to limit the legitimating power the law holds when it comes to undergirding the status quo: if activists were not making grand claims about the value of the law, states would be undermined in their efforts to use the law to legitimate business as usual. 
Part of the problem with this approach is that it substitutes an overblown account of the law's emancipatory potential with an alternative narrative that obscures how the law enables particular substantive policies to be furthered. A model of extraterritorial obligations in the economic sphere that is limited to narrow conceptions of direct or foreseeable harm, direct territorial control, or vague notions of cooperation maps onto a liberal economic model of laissez-faire, with a modicum of lighttouch regulation and modest social provision in exceptional areas, outside unusual situations where direct territorial control is exercised by a foreign state. International economic inequality is accepted as a given, bar narrow areas where there is more direct transboundary harm (only in the present), and the possibility of 'assistance,' which is unquantified and thereby left largely in the realm of charity and discretion. This model not only lacks more substantial socialist or solidaristic elements; for its proponents, of course, it would be conceived to be an alternative to a model with these elements. For an economist, international human rights law would appear to have come down on one side in the hugely contested debate about the operation of the global economy.

If this is correct, then it is not possible simply to assume that the ETO approach offers a modest, neutral foundation on which all manner of developments, including progressive, transformative, and solidaristic ones, might be possible. The foundation might determine that which is possible. It sets the trajectory that would, therefore, have to be altered, not followed, if different conceptions of international economic relations were to be attempted. More fundamentally, as a project of international human rights law, this initiative ends up legitimating the state-based international system that might be one of the structural causes of international economic inequality (cf. TWAIL critiques). Moreover, on its own terms, this system privileges states in the area of norm-generation and transformation. The modest nature of the ETO view of the current regime for extraterritoriality could be built upon not only by those who aspire to progressive development; it could also be captured by others who have very different priorities. 